УДК 378:355

Свгенія Іванченко, доктор педагогічних наук, професор, Військова академія, м. Одеса ORCID ID 0000-0003-3071-0938

Олександра Свірідюк, Військова академія, м. Одеса ORCID ID 0000-0003-4851-6631

DOI: $10.33099 / 2617-1775 / 2019-02 / 71-81$

\title{
ПЕДАГОГІЧНІ УМОВИ ФОРМУВАННЯ ГОТОВНОСТІ МАЙБУТНІХ ОФІЦЕРІВ ЗБРОЙНИХ СИЛ УКРАЇНИ ДО ЗАСТОСУВАННЯ SТЕМ- ТЕХНОЛОГІЙ У ПРОФЕСІЙНІЙ ДІЯЛЬНОСТІ
}

В статті представлено визначення поняття «педагогічні умови формування готовність майбутніх офіцерів Збройних Сил Украӥни до застосування STEM-технологій у професійній діяльності», під якими автори розуміють сукупність прийомів, методів, організаційних форм та обставин, щэо враховують особливості організачії навчальновиховного прочесу та дозволяють сформувати названу готовність у навчально-виховному середовищі вищого військового навчального закладу. Сформульовано педагогічні умови формування готовність майбутніх офіцерів Збройних Сил Украйни до застосування STЕМтехнологій у професійній діяльності.

Ключові слова: вища військова освіта; педагогічні умови; педагогічні умови формування готовності.

Постановка проблеми. Одним 3 пріоритетних напрямків реформування Збройних Сил (3С) України в умовах докорінних змін у зовнішньому та внутрішньому безпековому середовищі $\epsilon$ модернізація системи військової освіти. Згідно Стратегії національної безпеки України кардинального реформування сектору безпеки i оборони потребує «..вдосконалення механізмів правового, організаційного, кадрового зокрема системи підготовки офіцерських кадрів для Збройних Сил України...» [13].

Підготовка військового фахівця здатного виконувати свої професійні обов'язки, вміти користуватися необхідними технологіями для рішення військово-прикладних задач та постійно самовдосконалюватися протягом всього життя $є$ задачами військових вишів. Розв'язання цього завдання ми пов'язуємо із формуванням у майбутніх офіцерів готовності до застосування STEM-технологій у професійній діяльності у процесі професійної підготовки у вищих військових навчальних закладах (ВВН3), під якою ми розуміємо інтегровану якість особистості, що характеризується здатністю до взаємодії та взаємного впливу між всіма ланками системи управління, експлуатації i бойового застосування озброєння та військової техніки, а також спроможністю до створення i читання знакових систем, та складає базис для формування компетентностей майбутнього офіцера Збройних сил України, передбачених професійним стандартом. 
Однак, сам процес такої підготовки сьогодні вимагає втілення нових тенденцій розвитку освіти, нових технологій навчання, отже, потребує створення спеціальних умов.

Аналіз останніх досліджень i публікацій. Питанням визначення сутності поняття «педагогічна умова» присвячено низку робіт вчених різних поколінь, як-от: В. Андрєєва, В. Артемова, Ю. Бабанського, О. Бражнича, Б. Купріянова, А. Литвина, О. Міновської, О. Повтин, Р. Серьожникової та ін. Проте многогранність даного феномену відкидає можливість щодо однозначного визначення терміну «педагогічна умова», що потребує вибору певного підходу для кожного дослідження.

Проблемами формулювання педагогічних умов формування тієї чи тієї якості або компетентності курсантів у ВВНЗ в різні роки займались М. Кос, В. Монастирський, Р. Троцький та ін.., але аналіз наукових джерел засвідчив відсутність досліджень стосовно педагогічних умов формування готовності майбутніх офіцерів Збройних Сил України до застосування STEM-технологій у професійній діяльності.

Метою статті $\epsilon$ оприлюднення результатів теоретичного дослідження щодо виявлення педагогічних умов формування готовності майбутніх офіцерів Збройних Сил України до застосування STEM-технологій у професійній діяльності.

Методи дослідження: аналіз, синтез, систематизація наукової педагогічної літератури, нормативних документів, узагальнення.

Виклад основного матеріалу. Звернемось до понять «умова» та «педагогічна умова» у науковій літературі.

У академічному тлумачному словнику [12] серед пояснень терміну «умова» $є$ наступні:

- необхідна обставина, яка робить можливим здійснення, створення, утворення чого-небудь;

- сукупність даних, положення, що лежать в основі чого-небудь.

Отже, можна наголосити на тому, що для здійснення процесу формування готовності майбутніх офіцерів 3С України до застосування STEM-технологій у професійній діяльності необхідні певні обставини. При цьому, в широкому розумінні (за В.Загвязінським) «умова» може включати сукупність даних: причини, фактори розвитку, технології, методики, засоби навчання, виховання й розвитку, адміністративний супровід тощо. Саме таке розуміння «умови» ми приймаємо для свого дослідження.

Стосовно поняття «педагогічна умова» простежується відсутність єдності думок щодо нього, та вирізняються декілька напрямів його визначення та розуміння.

Так, Р. Серьожникова розкриває поняття «педагогічні умови» через сукупність об'єктивних можливостей, змісту, форм, методів, педагогічних прийомів [11].

В свою чергу, О. Бражнич [4] пояснює педагогічну умову через сукупність об' єктивних можливостей змісту, методів, організаційних форм i 
матеріальних можливостей здійснення педагогічного процесу, що забезпечує успішне досягнення поставленої мети.

За В. Андрєєвим [1, с. 124] педагогічна умова $\square$ це результат цілеспрямованого відбору, конструювання та застосування елементів змісту, методів (прийомів), а також організаційних форм навчання для досягнення конкретних цілей.

Педагогічні умови як чинники (обставини) розглядає Ю. Бабанський [3, с. 115], при цьому автор зазначає, що саме від цих чинників залежить ефективність функціонування педагогічної системи.

Ми погоджуємось $з$ твердженням, що педагогічні умови мають впливати на фізичний, психологічний, моральний розвиток людини, іiі навчання й виховання, формування особистості.

Також зазначимо, що педагогічна умова, як певна обстановка чи обставина, повинна впливати (гальмувати чи прискорювати) на формування та розвиток педагогічних явищ, процесів, систем, якостей особистості. Зрозуміло, що лише у комплексному поєднанні всіх вищезазначених шляхів розвитку людини є можливим всебічне формування особистості майбутнього офіцеру ЗС України під час освітнього процесу у ВВНЗ та у подальшому несенні військової служби.

При цьому усталеним фактом $є$ те, що вплив на освітній процес може бути не тільки внутрішнім, а зовнішнім, який є результатом функціонування політичної, соціально-економічної, освітньої та інших систем зовнішнього середовища, що реалізуються через відповідні соціальні інститути, та як частина завдання певного педагогічного процесу.

О. Повстин вважає, що педагогічні умови мають бути викладені у формі чітких правил із конкретним формулюванням (розроблення, забезпечення, супровід, підтримка тощо). Автор зазначає, що водночас до сукупності педагогічних умов доцільно включати приблизно рівноцінні за значимістю ключові психолого-педагогічні фактори (чинники) i соціально-педагогічні обставини [10].

3 погляду А. Артемова [2] педагогічна умова визначається, як необхідність створення такого простору, освітнього середовища, в якому представлена сукупність психолого-педагогічних та організаційно-методичних факторів, компонентів, відносин і засобів, що загалом забезпечує реалізацію необхідного педагогічного процесу як складної педагогічної системи, де з'являється та реалізується можливість формування професійної компетентності фахівця.

Останні тенденції щодо дослідження педагогічних умов (Б. Купріянов та О. Міновська [7] та ін.) засвідчують дещо інше розуміння цього поняття, підгрунтям якого $є$ семифакторна модель педагогічного процесу, що включає:

1) суб' єкт педагогічної діяльності (викладач або група викладачів);

2) об'єкт педагогічної діяльності (студент);

3) діяльність студента;

4) ставлення студента до діяльності; 
5) внутрішнє середовище освітнього закладу, яке засвоєне спільнотою студентів та викладачів;

6) соціальне середовище (зовнішне відносно освітнього закладу);

7) виховна діяльність як керування характеристиками діяльності студентів, внутрішнього та зовнішнього середовища, ставленням студента до діяльності.

В цьому випадку педагогічна умова виступає у вигляді складової закономірності педагогічного процесу, де закономірність $є$ усталеним зв'язком між керованим процесом змін студента та педагогічною умовою.

Формулюючи педагогічні умови формування мультиплікативної компетентності економіста у системі інтегративної професійної підготовки майбутніх економістів, Є. Іванченко [5] визначає педагогічні умови через спеціально створене навчально-виховне середовище, яке продукує обставини, що впливають на розвиток професійних та особистісних якостей студентів $\mathrm{i}$ врахування яких необхідно для ефективного формування компетентності економіста у процесі його інтегративної професійної підготовки.

Найбільш докладно поняття «педагогічні умови» розглянуто в роботах А. Литвина, який під педагогічними умовами розуміє комплекс спеціально спроектованих генеральних чинників впливу на зовнішні та внутрішні обставини навчально-виховного процесу й особистісні параметри всіх його учасників». При цьому автор зазначає, що педагогічні умови повинні забезпечувати цілісність навчання та виховання в інформаційно-освітньому середовищі навчального закладу відповідно до вимог суспільства та запитів ринку праці, сприяти всебічному гармонійному розвиткові особистості та створювати сприятливі можливості для виявлення ii задатків, врахування потреб i формування загальнолюдських i професійно важливих якостей, ключових кваліфікацій, загальних і професійних компетенцій [8].

Отже, враховуючи вищезазначене, під педагогічними умовами формування готовність майбутніх офіџерів ЗС України до застосування STEM-технологій у професійній діяльності ми будемо розуміти сукупність прийомів, методів, організаційних форм та обставин, які враховують особливості організації навчально-виховного процесу та дозволяють сформувати названу готовність у навчально-виховному середовищі ВВНЗ.

Доцільним є аналіз робіт вчених, які розглядали педагогічні умови крізь призму формування певних конкретних якостей курсантів (слухачів) ВВНЗ.

У своєму дослідженні Р. Троцький [15] виділяє організаційно-педагогічні умови ефективного формування готовності курсантів до управлінської діяльності:

- оновлення змісту, методів і форм фахової підготовки 3 метою формування готовності до управлінської діяльності курсантів (оновлення змісту фахових дисциплін шляхом збагачення тематики застосування форм навчальної діяльності; організація методичних, науково-методичних семінарів для викладачів, розроблення робочих навчальних програм), 
- науково методичних; активізацію науково-дослідницької та самостійної роботи курсантів 3 метою формування їхньої готовності до управлінської діяльності у процесі фахової підготовки (організація науково-дослідної діяльності курсантів, проведення консультацій, здійснення проектної діяльності 3 питань ефективності управлінською діяльністю);

- розроблення навчально-методичного супроводу формування готовності до управлінської діяльності курсантів у процесі фахової підготовки.

Ряд науковців (І. Медвідь, Б. Бородін та ін..) розглядали готовність до службово-бойової діяльності майбутніх офіцерів запасу та відзначили, що ефективність формування цієї готовності залежить від реалізації наступних умов:

- збільшення чисельності занять за певними напрямками у структурі плану підготовки офіцерів запасу (психологічної, вогневої та фізичної підготовки);

- збільшення чисельності практичних занять у структурі плану підготовки офіцерів запасу (зокрема, проведення занять на тренажерах військової техніки на території військової частини);

- залучення до підготовки здобувачів, які навчаються за програмою підготовки офіцерів запасу, учасників бойових дій.

Сучасні інформаційні технології дозволяють розширювати коло професійної підготовки офіцерів. Наприклад, питанням використання імітаційного моделювання тактичного рівня у професійної підготовки майбутніх офіцерів розглядає М. Кос. У своєму дослідженні він сформулював наступні педагогічні умови:

- використання адаптованих для українських збройних сил методик НАТО для навчання майбутніх офіцерів;

- максимальне наближення до реальних бойових ситуацій у IKI шляхом використання конкретних сценаріїв, які передбачають багаторазове повторення та коригування професійних дій;

- розроблення консультативних матеріалів для підготовки викладачів та психологічний супровід, спрямований на усвідомлення майбутніми офіцерами ролі IКI як засобу збереження живої сили в реальних бойових ситуаціях, формування лідерських якостей офіцерів, формування креативного професійного мислення [6].

В. Монастирський [9] для висування педагогічних умов військовопрофесійної підготовки майбутніх офіцерів 3С України враховує такі чинники:

- рівень базової військової підготовки громадян;

- систематична i безперервна мотивація опанування громадянами професійних умінь і навичок;

- запровадження професійних умінь і навичок;

- запровадження діяльнісного підходу у формуванні інтересу тих, хто навчається, до служби в ЗС України та інших державних військових формуваннях; 
- упровадження в освітній процес перспективних сучасних технологій навчання;

- спонукання майбутніх офіцерів до саморозвитку, самовдосконалення i постійного самостійного оновлення знань, умінь, навичок;

- удосконалення форм і методів навчально-методичної роботи науковопедагогічних працівників навчального підрозділу закладу вищої освіти.

При цьому дослідник формулює наступні педагогічні умови: розгляд військово-професійної підготовки як складової державної системи професійної освіти України, проектування моделі військово-професійної підготовки, а також використання в освітньому процесі сучасних технологій навчання, які $€$ основою оптимізації військово-професійної підготовки майбутніх офіцерів.

Ми вважаємо, що формування готовності майбутніх офіцерів ЗСУ до застосування STEM-технологій у професійній діяльності повинно базуватися на інтеграції природничих дисциплін, що (за О. Ростовською) відображає сутність фундаменталізації освітнього процесу та сприяє міждисциплінарним зв’язкам, науково-дослідній роботі всіх учасників освітнього процесу тощо.

Саме тому першою педагогічною умовою ми виокремили: посилення підготовки $з$ природничих дисциплін із застосуванням STEM-технологій під час проведення навчальних занять, розглядаючи фундаменталізацію освіти як процес формування «фундаментально-знаннєвого» каркасу особистості (ядра системи знань індивіда), що (за Е. Соколовою) забезпечить системність знань, цілісне сприйняття світу й людини в ньому, створення бази для професійної культури й майстерності.

Ми впевнені, що для формування готовності майбутніх офіцерів ЗС України до застосування STEM-технологій у професійній діяльності $\epsilon$ необхідним занурення курсантів (слухачів) у такий освітній процес, який передбачає використання цих самих STEM-технологій, демонстрація їх дієвості у повсякденній діяльності майбутніх офіцерів. Наочний приклад, постійне зіткнення із зазначеними технологіями під час навчального процесу, особливо під час розв'язання військово-прикладних завдань на заняттях 3 дисциплін як циклу загальної, так і професійної підготовки, викликає необхідне сприйняття та позитивну мотиваційну настанову.

Отже, на наш погляд, дуже важливою умовою є створення позитивної мотиваційної настанови на нетрадиційний підхід у навчальному процесі під час формування готовності майбутніх офіцерів 3С України до застосування STEMтехнологій у професійній діяльності. Саме це положення ми пропонуємо як другу педагогічну умову формування зазначеної готовності.

У структурі особистості мотивація займає одне 3 провідних місць. Мотиваційна сфера (за В. Асеевим; Д. Леонтьевим, В. Мерлином та ін..) розглядається як визначальна ланка в діяльності, що зумовлює цілеспрямований, свідомий характер дій людини і виступає центральною в процесі розвитку особистості. А у структурі навчально-професійної самореалізації мотиваційна складова визначається як системотворча.

Фахівці професійної освіти розглядають поняття «професіоналізм», як: 
- здатність до компетентного виконання професійних обов’язків, набуту в ході навчальної і практичної діяльності;

- рівень майстерності та мистецтва в певному виді занять, який відповідає рівню складності виконуваних завдань;

- інтегральну якість суб'єкта, яка характеризує продуктивне виконання професійних завдань (в нашому випадку - рішення військово-прикладних задач) має бути обумовлена творчою самодіяльністю, адекватною до змісту та вимогам професійної діяльності.

Згідно вищезазначеного доходимо висновку, що процеси творчого пошуку у професійній діяльності майбутніх офіцерів 3С України є неминучими, як, власне, i прояви особистісних компетенцій. За В. Татенко [14], прояв компетентностей при розв’язанні творчих завдань, що мають проблемний характер, потребують знаходження нових підходів та нестандартних рішень. Чим більше креативності, тим вищий рівень компетентності, бо саме в творчому процесі розкриваються глибинні закони існування сущого, а креативність особистості стати неформальним лідером у професійному середовищі.

Тому, ми вважаємо за необхідне формулювання третьої педагогічної умови $\square$ активізація постійного самовдосконалення та творчого пошуку майбутніх офіцерів ЗС України під час розв’язання військово-прикладних задач.

Активізація важливих особистих мотивів підхоплює мотивацію до самовдосконалення, а постійність цього процесу може досягатися лише бажанням особистості бути професіоналом. Внаслідок цього, важливим $\epsilon$ усвідомлення того, що наявність досвіду, високий рівень знань теорії та практики не є показником професіоналізму, однак є суттєвим фундаментом для подальшого розвитку, самореалізації та самовдосконалення. А створення умов для творчого пошуку майбутніх офіцерів 3С України під час рішення військово-прикладних задач $\epsilon$ передумовою творчого підходу під час виконання службових обов’язків на посадових місцях у військах.

Висновки та перспективи подальших досліджень. Таким чином, нами визначено сутність поняття «педагогічні умови формування готовність майбутніх офіцерів 3C України до застосування STEM-технологій у професійній діяльності» та встановлено, що необхідними педагогічними умовами формування зазначеної якості майбутніх офіцерів 3С України є:

1) посилення підготовки 3 природничих дисциплін iз застосуванням STEM-технологій під час проведення навчальних занять;

2) створення позитивної мотиваційної настанови на нетрадиційний підхід у навчальному процесі під час формування готовності майбутніх офіцерів 3С України до застосування STEM-технологій у професійній діяльності;

3) активізація постійного самовдосконалення та творчого пошуку майбутніх офіцерів ЗС України під час розв’язання військово-прикладних задач. 
Подальші розвідки вбачаємо у грунтовному розкритті змісту запропонованих педагогічних умов та створенні моделі щодо їх реалізації у навчально-виховному середовищі ВВНЗ.

\section{ЛІТЕРАТУРА}

1. Андреев, В.И. (2000). Педагогика. Учебный курс для творческого саморазвития : 2е изд. Казань : Центр инновационных технологий, 600.

2. Артемов, В.Ю. (2015) Теоретичні та методичні основи формування деонтологічної компетентності фахівців із організації захисту інформації з обмеженим доступом: дис. д-ра пед. наук: 13.00 .04 «Теорія та методика професійної освіти», Київ.

3. Бабанский, Ю.К. (1989) Избранные педагогические труды. М.: Педагогика. 560.

4. Бражнич, О.Г. (2001) Педагогічні умови диференційованого навчання учнів загальноосвітньої школи: дис. канд. пед. наук: 13.00.09 «Теорія навчання», Кривий Ріг.

5. Іванченко, Є.А. (2009) Щодо педагогічних умов формування компетентності економіста в системі інтегративної професійної підготовки майбутніх економістів. Науковий вісник Південноукраїнського державного педагогічного університету ім. К. Д. Ушинського: Одеса, 1-2, 139-144.

6. Кос, М. (2018) Педагогічні умови використання імітаційного моделювання тактичного рівня у процесі професійної підготовки майбутніх офіцерів. Науковий вісник Інституту професійно-технічної освіти НАПН України. Сер. : Професійна педагогіка, 16, 136-141.

7. Куприянов, Б.В., Миновская, О.В. Ситуационно-ролевая игра как средство развития у подростков субъектности во взаимодействии. - URL: http://www.altruism.ru/sengine.cgi/5_9_9.html/28/13/3?page=\&print=1\%3E (дата звернення: 19.02.2018)

8. Литвин, А.В. (2014) Методологічні засади поняття «педагогічні умови»: на допомогу здобувачам наукового ступеня. Львів: СПОЛОМ, 76.

9. Монастирський, В. М. (2019) Педагогічні умови військово-професійної підготовки майбутніх офіцерів збройних сил України та правоохоронних органів держави у військових навчальних підрозділах ЗВО. Вісник Черкаського університету. Серія: Педагогічні науки, 1, $165-170$.

10. Повстин, О.В. Педагогічні умови ефективного формування управлінської компетентності у фахівців у галузі безпеки людини. URL: http://nbuv.gov.ua/jpdf/Profos_2018_14_8.pdf (дата звернення: 19.05.2019)

11. Серьожникова Р.К., Пархоменко Н.Д., Яковицька Л.С. (2003) Основи психології і педагогіки: навч. посібник. Київ : Центр навч. літератури, 243.

12. Словник української мови. Академічний тлумачний словник URL: http://sum.in.ua/s/umova/ (дата звернення: 19.05.2019)

13. Стратегія національної безпеки України: Указ Президента України від 26 травня 2015 року № 287/2015. URL: https://zakon.rada.gov.ua/laws/show/287/2015\#n7 (дата звернення: 13.09.2019)

14. Татенко В. (2003) Психологічні ознаки професійоналізму. Психологічні перспективи: зб статей ВДУ ім. Лесі Українки, Інститут соціальної і політичної психології АПН України. Луцьк, 161-166.

15. Троцький Р.С. (2018) Формування готовності до управлінської діяльності у курсантів вищих навчальних закладів МВС України у фаховій підготовці: дис.. канд.. пед.. наук : 13.00. 04 «Теорія і методика професійної освіти», Київ. 


\section{REFERENCES}

1. Andreev, V.I. (2000). Pedagogika. Uchebnyiy kurs dlya tvorcheskogo samorazvitiya [Pedagogics. Training course for creative self-development] : 2-e izd. Kazan : Tsentr innovatsionnyih tehnologiy, 600. (in Russian)

2. Artemov, V.Iu. (2015) Teoretychni ta metodychni osnovy formuvannia deontolohichnoi kompetentnosti fakhivtsiv iz orhanizatsii zakhystu informatsii $\mathrm{z}$ obmezhenym dostupom [Theoretical and methodological bases of deontological formation competency of limited access information security professionals] : dys. d-ra ped. nauk: 13.00.04 «Teoriia ta metodyka profesiinoi osvity», Kyiv. (in Ukrainian)

3. Babanskiy, Yu.K. (1989) Izbrannyie pedagogicheskie trudyi [Chosen pedagogical works]. M.: Pedagogika. 560. (in Russian)

4. Brazhnych, O.H. (2001) Pedahohichni umovy dyferentsiiovanoho navchannia uchniv zahalnoosvitnoi shkoly [Pedagogical conditions of the differentiated education of secondary school's pupils] : dys. kand. ped. nauk: 13.00.09 «Teoriia navchannia», Kryvyi Rih. (in Ukrainian)

5. Ivanchenko, Ye.A. (2009) Shchodo pedahohichnykh umov formuvannia kompetentnosti ekonomista $\mathrm{v}$ systemi intehratyvnoi profesiinoi pidhotovky maibutnikh ekonomistiv [On pedagogical conditions of economist's competence formation in the system of future economists's integrative professional preparation]. Naukovyi visnyk Pivdennoukrainskoho derzhavnoho pedahohichnoho universytetu im. K. D. Ushynskoho: Odesa, 1-2, 139-144. (in Ukrainian)

6. Kos, M. (2018) Pedahohichni umovy vykorystannia imitatsiinoho modeliuvannia taktychnoho rivnia u protsesi profesiinoi pidhotovky maibutnikh ofitseriv [Pedagogical conditions for the use of tactical-level simulation in the future officers $\square \mathrm{s}$ preparation]. Naukovyi visnyk Instytutu profesiino-tekhnichnoi osvity NAPN Ukrainy. Ser. : Profesiina pedahohika, 16, 136-141. (in Ukrainian)

7. Kupriyanov, B.V., Minovskaya, O.V. Situatsionno-rolevaya igra kak sredstvo razvitiya u podrostkov sub'ektnosti vo vzaimodeystvii [Situational role-play as a means of development in adolescents subjectivity in interaction]. URL: http://www.altruism.ru/sengine.cgi/5_9_9.html/ 28/13/3? page $=\&$ print $=1 \% 3 \mathrm{E}$ (reference date: 13.02 .2018 r.) (in Russian)

8. Litwin, A.V., 2014. Metodolohichni zasady ponyattya "pedahohichni umovy": na dopomohu zdobuvacham naukovoho stupenya [Methodological principles of the concept of "pedagogical conditions": to help applicants ofscientific degree.] Lviv: SPOLOM. (in Ukrainian)

9. Monastyrskyi, V. M. (2019) Pedahohichni umovy viiskovo-profesiinoi pidhotovky maibutnikh ofitseriv zbroinykh syl Ukrainy ta pravookhoronnykh orhaniv derzhavy u viiskovykh navchalnykh pidrozdilakh ZVO [Pedagogical Conditions of Military-Professional Training of Future Officers of the Armed Forces of Ukraine and Law Enforcement Agencies in Military Training Units of Higher Education Institutions]. Visnyk Cherkaskoho universytetu. Seriia: Pedahohichni nauky, 1, 165-170. (in Ukrainian)

10. Povstyn, O.V. Pedahohichni umovy efektyvnoho formuvannia upravlinskoi kompetentnosti u fakhivtsiv u haluzi bezpeky liudyny [Pedagogical conditions for the effective formation of managerial competence in human security professionals]. URL: http://nbuv.gov.ua/jpdf/Profos_2018_14_8.pdf (reference date: 19.05.2019)

11. Serozhnykova R.K., Parkhomenko N.D., Yakovytska L.S. (2003) Osnovy psykholohii i pedahohiky [Fundamentals of psychology and pedagogics]: navch. posibnyk. Kyiv : Tsentr navch. literatury, 243. (in Ukrainian)

12. Slovnyk ukrainskoi movy. Akademichnyi tlumachnyi slovnyk [Dictionary of the Ukrainian language. Academic Interpretative Dictionary]. URL: http://sum.in.ua/s/umova/ (data zvernennia: 19.05.2019) (in Ukrainian)

13. Stratehiia natsionalnoi bezpeky Ukrainy [National Security Strategy of Ukraine]: Ukaz Prezydenta Ukrainy vid 26 travnia 2015 roku № 287/2015. URL: https://zakon.rada.gov.ua/laws/show/287/2015\#n7 (reference date: 13.09.2019) (in Ukrainian) 
14. Tatenko V. (2003) Psykholohichni oznaky profesiionalizmu [Psychological signs of professionalism]. Psykholohichni perspektyvy: zb statei VDU im. Lesi Ukrainky, Instytut sotsialnoi i politychnoi psykholohii APN Ukrainy. Lutsk, 161-166. (in Ukrainian)

15. Trotskyi R.S. (2018) Formuvannia hotovnosti do upravlinskoi diialnosti u kursantiv vyshchykh navchalnykh zakladiv MVS Ukrainy u fakhovii pidhotovtsi [Formation of readiness for management activity in cadets of higher educational establishments of the Ministry of Internal Affairs of Ukraine in professional training] : dys.. kand.. ped.. nauk : 13.00. 04 «Teoriia i metodyka profesiinoi osvity», Kyiv. (in Ukrainian)

\section{PЕЗЮМЕ}

Евгения Иванченко, доктор педагогических наук, профессор, Военная академия, г. Одесса

Александра Свиридюк, Военная академия, г. Одесса

\section{Педагогические условия формирования готовности будущих офицеров Вооруженных Сил Украини к использованию STEM-технологий в професиональной деятельности}

В статье представлено определение понятия «педагогические условия формирования готовности будущих офицеров Вооруженных Сил Украины к применению STЕМ-технологий в профессиональной деятельности», под которыми авторы понимают совокупность приемов, методов, организационных форм и обстоятельств, учитывающих особенности организации учебно-воспитательного процесса и позволяющих сформировать названную готовность в учебно-воспитательной среде высшего военного учебного заведения. Сформулированы педагогические условия формирования готовности будущих офицеров Вооруженных Сил Украинь $к$ применению STEM-технологий в профессиональной деятельности.

Ключевые слова: высшее военное образование; педагогические условия; педагогические условия формирования готовности.

\section{SUMMARY}

Ievgeniia Ivanchenko Doctor of Science (Pedagogical), Professor, Military Academy c. Odessa Oleksandra Sviridiuk, Military Academy c. Odessa

\section{Pedagogical conditions for formation of readiness of the Armed Forces' future officers of Ukraine for application of STEM-technologies in professional activity}

Introduction. One of the priorities of the reform of the Ukraine Armed Forces is the modernization of the military education system. The authors associate this mission with the formation of readiness Armed Forces' future officers of Ukraine for using STEM-technologies in professional activities during professional training in higher military educational institutions. The process of such preparation today requires the creation of special conditions.

Purpose. To publish the results of the theoretical study on the identification of pedagogical conditions for formation readiness of Armed Forces' future officers of Ukraine for using STEMtechnologies in professional activities. 
Methods of research: analysis, synthesis, systematization of scientific pedagogical manuals, normative documents, generalization.

Results. Based on the analysis of scientific-psychological and scientific-pedagogical literature, the concept of "Pedagogical conditions for formation readiness of Armed Forces' future officers of Ukraine for using STEM-technologies in professional activities" has been synthesized, which is defined as a set of techniques, methods, organizational forms and circumstances, which take into account the peculiarities of the organization of the educational process and allow to form the readiness in the educational-upbringing environment of the higher military educational institution.

Within studies such conditions have chosen: 1) to strengthen training in natural disciplines using STEM-technologies during training sessions; 2) creating positive motivational guidance on non-traditional approach in the educational process while forming formation readiness of Armed Forces' future officers of Ukraine for using STEM-technologies in professional activities; 3) activation of constant self-improvement and creative search of Armed Forces' future officers of Ukraine during military-applied tasks.

Originality. The definition of the concept "Pedagogical conditions of formation readiness of Armed Forces' future officers of Ukraine for using STEM-technologies in professional activities" is presented and pedagogical conditions themselves are specified.

Conclusion. The essence of the concept "Pedagogical conditions of formation readiness of Armed Forces' future officers of Ukraine for using STEM-technologies in professional activities" has been defined and the necessary pedagogical conditions of formation of the specified quality of Armed Forces' future officers of Ukraine have been established.

Keywords: the higher military education; pedagogical conditions; pedagogical conditions of formation of readiness. 